\title{
Perubahan Mutu Tomat (Lycopersicon esculentum Mill.) Dengan Variasi Konsentrasi Pelapisan Gel Lidah Buaya (Aloe vera L.) Dan Suhu Penyimpanan
}

\section{(Changes in quality of Tomato (Lycopersicon esculentum Mill.)With Coating Concentration Variation Gelsof Aloe Vera (Aloe vera L.) And Storage Temperature)}

\author{
Rina Marwina,Raida Agustina,Bambang Sukarno Putra \\ Program Studi Teknik Pertanian, Fakultas Pertanian, Universitas Syiah Kuala
}

\begin{abstract}
Abstrak. Penelitian ini bertujuan untuk melihat lama umur simpan buah tomat dengan menggunakan lapisan gel lidah buaya (Aloe vera L.) dengan berbagai variasi konsentrasi dan variasi suhu penyimpanan.Penelitian ini menggunakan tomat dengan tingkat kematangan optimum. Pada variasi konsentrasi gel lidah buaya (A) terdiri atas 4 perlakuan, yaitu tanpa gel lidah buaya $\left(A_{1}\right)$, konsentrasi $30 \%\left(A_{2}\right)$, konsentrasi $50 \%\left(A_{3}\right)$ dan konsentrasi $70 \%$ $\left(\mathrm{A}_{4}\right)$, dan variasi penyimpanan yaitu suhu penyimpanan $(\mathrm{B})$ terdiri atas 2 perlakuan, yaitu suhu $\mathrm{B}_{1}$ suhu ruang $\left(28^{\circ} \mathrm{C}\right.$ ) dan $\mathrm{B}_{2}$ (suhu rendah $10^{\circ} \mathrm{C}$ ). Analisa data yang diamati meliputi susut bobot, kekerasan, vitamin $\mathrm{C}$, total padatan terlarut, dan uji organoleptik (warna, tekstur, dan aroma).Dari hasil penelitian didapatkan perlakuan terbaik pada tomat dengan perlakuan konsentrasi gel lidah buaya $30 \%$ pada penyimpanan suhu rendah $10^{\circ} \mathrm{C}$ masih diterima konsumen hingga hari ke 21. Penyimpanan perlakuan terbaik pada hari ke-12 untuk analisis susut bobot terdapat pada perlakuan konsentrasi gel lidah buaya $30 \%$ yang disimpan pada suhu $10^{\circ} \mathrm{C}$ dengan nilai $15,52 \%$, untuk analisis presentase kekerasanperlakuan terbaik terdapat pada konsentrasi $30 \%$ pada suhu rendah $10^{\circ} \mathrm{Cnilai}$ yaitu $1.357 \mathrm{~kg} / \mathrm{cm}^{2}$, dan analisis vitamin $\mathrm{C}$ perlakuan terbaik terdapat pada konsentrasi $30 \%$ pada suhu rendah $10^{\circ} \mathrm{Cnilai} 1,42 \mathrm{mg} / 50 \mathrm{gr}$, sedangkan TPT perlakuan terbaik terdapat pada suhu rendah $10^{\circ} \mathrm{Cdengan}$ perlakuan tanpa konsetrasi gel lidah buaya nilai presentase yaitu 4,40 \%Brix. Dari hasil pengujian organoleptik, panelis menolak tomat dengan perlakuan konsentrasi gel lidah buaya $30 \%$ yang disimpan pada suhu ruang $28^{\circ} \mathrm{C}$ pada hari penyimpanan ke-12, sedangkan pada penyimpanan suhu rendah $10^{\circ} \mathrm{C}$ panelis menolak tomatdengan konsentrasi gel lidah buaya $30 \%$ pada hari penyimpanan ke-21.
\end{abstract}

Kata kunci :Perubahan Mutu Tomat, Variasi Konsentrasi Pelapisan Gel Lidah Buaya, Suhu penyimpanan.

Abstract. This study aimed to look at the old the shelf life of tomatoes by using the layer of gels of aloe vera (Aloe vera L.) with various concentrations and a temperature variations in of storage. This study uses the tomatoes with optimum maturity level. In a variation of concentration of aloe gel (A) composed of 4 treatment, ie without aloe vera gel (A1), the concentration of $30 \%$ (A2), the concentration of $50 \%$ (A3) and a concentration of 70\% (A4), and a variety of storage ie storage temperature $(\mathrm{B})$ consisting of two treatments, namely $\mathrm{B} 1$ temperature room temperature $(28 \mathrm{oC})$ and B2 (low temperature $10 \mathrm{oC})$. Analysis of observed data include weight loss, violence, vitamin $\mathrm{C}$, total dissolved solids, and organoleptic (color, texture, and aroma). From the results, the best treatment in tomatoes by treatment with $30 \%$ aloe vera gel at low temperature storage is still acceptable to consumers $10^{\circ} \mathrm{C}$ until the 21 st day storage best treatment on day 12 for analysis of weight loss treatment concentration contained in aloe vera gel $30 \%$ stored at a temperature of $10^{\circ} \mathrm{C}$ with a value of $15.52 \%$, for the analysis of the percentage of violence are the best treatment at a concentration of $30 \%$ at low temperature $10^{\circ} \mathrm{C}$ value is $1,357 \mathrm{~kg} / \mathrm{cm} 2$, and the analysis of vitamin $\mathrm{C}$ are the best treatment at a concentration of $30 \%$ at low temperature $10^{\circ} \mathrm{C}$ value $1.42 \mathrm{mg} /$ 50gr, while TPT best treatment there at low temperature $10^{\circ} \mathrm{C}$ with treatment without concentration of aloe gel percentage value that is $4.40 \%$ Brix. From the results of organoleptic tests, the panel rejected the tomatoes by treatment with $30 \%$ aloe vera gel is stored at room temperature $280 \mathrm{C}$ on the 12 th day of storage, while the low temperature storage $10 \mathrm{oC}$ panelists refused tomatoes with aloe vera gel concentration of $30 \%$ on the day of deposit of the 21 .

Keywords:Quality Changes Tomato, Variation concentration of of Aloe VeraGels Coatings, Temperature storage 


\section{PENDAHULUAN}

Salah satu parameter untuk menilai kualitas tomat adalah penampilan kulit tomat terutama dalam hal warna dan kemulusannya. Penampakan kulit yang baik dan menarik akan mempengaruhi selera konsumen. Upaya menghasilkan kulit tomat dan menarik dapat dilakukan melalui teknologi pencelupan dalam gel lidah. Pelapisan buah dengan gel lidah buayamerupakan salah satu cara untuk mempertahankan masa simpan buah. Edible coating adalah lapisan tipis yang dapat dimakan yang digunakan pada makanan dengan cara pembungkusan, pencelupan, penyikatan, atau penyemprotan untuk memberikan penahanan yang selektif terhadap perpindahan gas, uap air, dan bahan terlarut serta perlindungan terhadap kerusakan mekanis. Komponen penyusun edible coating mempengaruhi secara langsung bentuk morfologi maupun karakteristik coating yang dihasilkan.

Pelapisan gel lidah buaya yang dilakukan dalam penelitian ini adalah pembuatan gel lidah buayayang berasal dari gel tanaman lidah buaya.Lidah buayajuga mengandung beberapa senyawa bioaktif yang bersifat antimikroba dan dapat menyembuhkan luka jaringan sehingga diharapkan pada pelapisan gel lidah buaya mampu mempertahankan mutu serta memperpanjang masa simpan sayuran tomat. Valverde et all. (2006) yang menggunakan gel lidah buaya untuk melapisi buah anggur crimson, berhasil memperpanjang umur simpan buah anggur dari 7 hari menjadi 35 hari.

Penyimpanan pada suhu ruang menyebabkan penurunan mutu fisik dan nilai gizi yang lebih cepat diikuti dengan proses pembusukandibandingkan suhu rendah. Penyimpanan pada suhu rendah dapat menghambat kerusakan makanan, antara lain kerusakan fisiologis, kerusakan enzimatis maupun kerusakan mikrobiologis. Pada pengawetan dengan suhu rendah dibedakan antara pendinginan dan pembekuan. Pendinginan dan pembekuan merupakan salah satu cara pengawetan yang tertua. Penelitian ini bertujuan untuk melihat lama umur simpan buah tomat dengan menggunakan lapisan gel lidah buaya (Aloe vera L.) dengan berbagai variasi konsentrasi dan variasi suhu penyimpanan.

\section{METODE PENELITIAN}

Penelitian ini Bulan Desember 2014 di Laboratorium Pasca Panen Program StudiTeknik Pertanian dan Laboratorium Teknologi Hasil Pertanian, Fakultas Pertanian,Universitas Syiah Kuala, Darussalam Banda Aceh.

\section{Alat dan Bahan}

Alat-alat yang digunakan dalam penelitian ini adalah Fruit Hardness tester, Refraktometer, Blender, lemari pendingin, timbangan digital, dan bahan utama yang digunakan adalah buah tomat segar yang didapatkan dari Aceh Tengah, daun lidah buaya dari Banda Aceh. Bahan lainnya yang diperlukan adalahair matang, aquades.

\section{Metode Penelitian}

Tomat yang digunakan jenis tomat yang berasal dari Aceh Tengah dan lidah buaya berasal dari Banda Aceh.Variasi konsentrasi gel lidah buaya adalah 70\%, 50\%, 30\%.Variasi suhu penyimpanan dalam suhu ruang dan suhu rendah $10^{\circ} \mathrm{C}$. Analisa yang digunakan adalah susut bobot, kekerasan, uji vitamin $\mathrm{C}$, total padatan terlarut, organoleptik (warna, aroma, tekstur). 


\section{Susut Bobot}

Menurut (Gardjito dan Wardana, 2003)rumus susut bobot dapat dicari persentasenya dengan menggunakan rumus :

$\%$ Susut bobot $=\frac{\text { Bobot awal }- \text { Bobot akhir }}{\text { Bobot awal }} \times 100 \%$

\section{Kekerasan}

Menurut Sudarmadji dkk. (1997)Rumus yang digunakan untuk menghitung tekanan dari data yang diperoleh dari alat pembacaan adalah :

$$
\sigma=\frac{P}{A}
$$

\section{Uji Kadar Vitamin C}

Menurut Apriyantono dkk.(1989)Pengujian kadar Vitamin C adalah dalam bentuk Asam Askorbat. Dua puluh lima (25) ml filtrat dititrasi dengan larutan Iod 0,01 N, ditambahkan indikator amilum pada filtrat sebelum dititrasi.

Asam askorbat $(\mathrm{mg} / 50 \mathrm{gr}$ bahan $)=\frac{m l-I o d .0,01 N \times 0,88 \times P \times 100}{\text { grambobotbahan }}$

\section{Total Padatan Terlarut}

Total Padatan Terlarut dihitung dengan menggunakan refraktometer abbe.Kandungan TPT dibaca dengan satuan \%Brix. Menurut Apriyatono, (1989)

\section{Uji Organoleptik}

Uji Organoleptik meliputi warna, aroma, dan tekstur.

\section{HASIL DAN PEMBAHASAN}

\section{Umur Simpan}

Lama penyimpanan susut bobot, kekerasan, uji vitamin $\mathrm{C}$, total padatan terlarut, dan organoleptik (warna, aroma, tekstur) tomat yang dilapisi dengan konsentrasi perlakuan gel lidah buaya yang sudah ditolak oleh panelis dapat dilihat pada Tabel 1.

Tabel 1. Lama penyimpanan tomat selama penyimpanan

\begin{tabular}{cc}
\hline Perlakuan & $\begin{array}{c}\text { Lama Penyimpanan } \\
\text { (Hari) }\end{array}$ \\
\hline $\mathrm{A}_{1} \mathrm{~B}_{1}$ & 12 \\
$\mathrm{~A}_{2} \mathrm{~B}_{1}$ & 9 \\
$\mathrm{~A}_{3} \mathrm{~B}_{1}$ & 9 \\
$\mathrm{~A}_{4} \mathrm{~B}_{1}$ & 9 \\
$\mathrm{~A}_{1} \mathrm{~B}_{2}$ & 15 \\
$\mathrm{~A}_{2} \mathrm{~B}_{2}$ & 21 \\
$\mathrm{~A}_{3} \mathrm{~B}_{2}$ & 21 \\
$\mathrm{~A}_{4} \mathrm{~B}_{2}$ & 21 \\
\hline
\end{tabular}


Pada konsentrasi A1B1 terjadi penolakan pada hari ke 12, sedangkan konsetrasi A2B1, A3B1, A4B1 terjadi penolakan oleh panelis pada hari ke 9, pada konsentrasi A1B2 terjadi penolakan pada hari ke 15, sedangkan konsentrasi A2B2, A2B3, A4B2 terjadi penolakan oleh panelis pada hari ke 21 .

\section{Susut Bobot}

Hasil penelitian nilai susut bobot buah tomat dengan berbagai rata-rata perlakuan konsentrasi selama penyimpanan hari $0,3,6,9,12,15,18$ dan 21 nilai susut bobot berkisar antara $0,52 \%-31,88 \%$. Grafik dapat dilihat pada Gambar 1 .

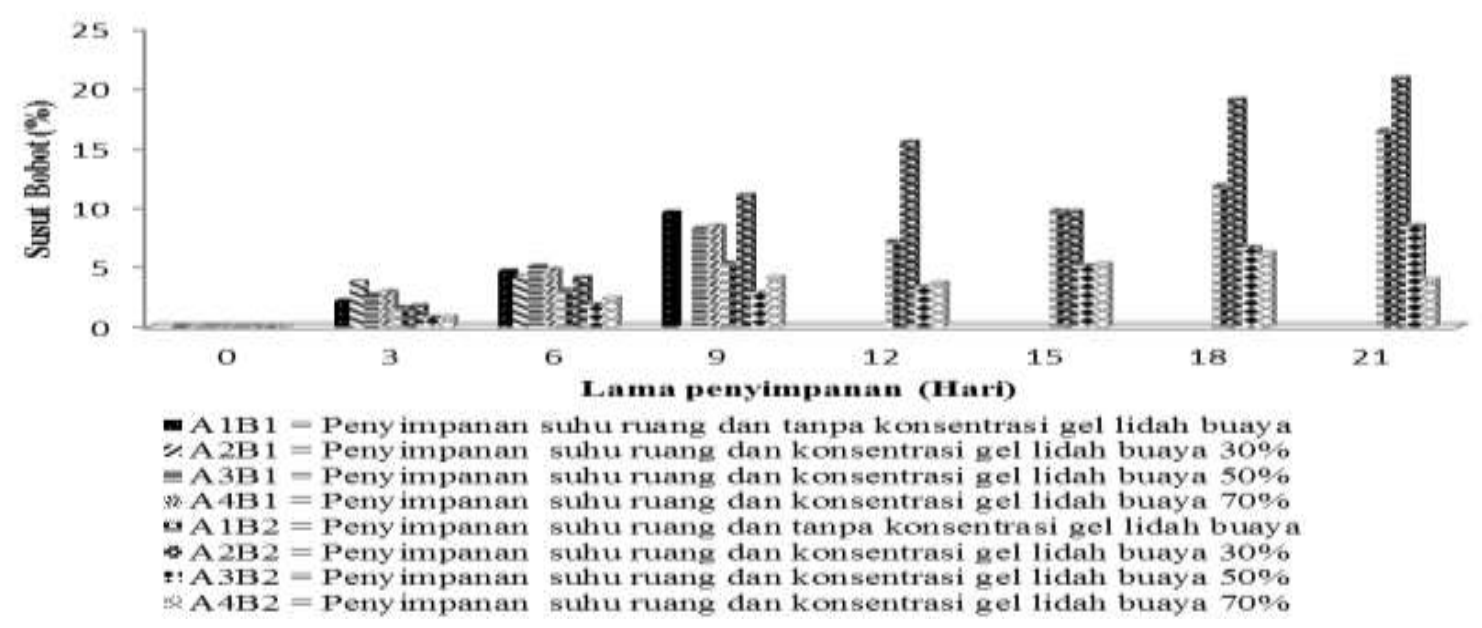

Gambar 1. Susut bobot tomat pada berbagai perlakuan konsentrasi gel lidahbuaya dan suhu ruang

Gambar 1 terlihat bahwa persentase susut bobot rata-rata tomat pada penyimpanan suhu ruang dengan konsentrasi gel lidah buaya bertahan hingga hari ke 9, pada penyimpanan suhu rendah $10^{\circ} \mathrm{C}$ dengan konsentrasi gel lidah buaya bertahan hingga hari ke 21 . Sedangkan perlakuan terbaik terdapat pada konsentrasi A2B2 yaitu 20,87\%. Terjadinya susut bobot tomat selama 21 hari penyimpanan dikarenakan kelebihan kandungan air pada bahan pada saat penyimpanan, khususnya pada penyimpanan suhu ruang. Susut bobot merupakan salah satu faktor yang digunakan dalam mengidentifikasi mutu fisik buah selama penyimpanan.Mutu buah tomat sangat dipengaruhi oleh lamanya penyimpanan serta perlakuan-perlakuan yang diberikan.Selama penyimpanan, tomat akan mengalami susut bobot dalam pengertian seharihari, biasanya istilah susut hanya diartikan sebagai bagian berat (bobot) yang hilang karena adanya suatu proses. Sedangkan yang dimaksud susut kuantitas yaitu kesusutan yang jelas terjadi dan dapat diukur dengan satuan berat.Susut kualitas yaitu kesusutan dengan berakibat dengan mengurangi harga serta menurunkan nilai gizi dari bahan pangan tersebut.Biasanya terjadi peristiwa susut bobot yang berkaitan antara susut kualitas dan kuantitas, biaya, tenaga dan waktu (Hartono, 1993).

\section{Kekerasan}

Hasil penelitian ini didapatkan kekerasan buah tomat selama penyimpanan berkisar antara0,003 $\mathrm{kg} / \mathrm{cm}^{2}-0,022 \mathrm{~kg} / \mathrm{cm}^{2}$. Hasil yang diinginkan dari penelitian ini adalah nilai 
kekerasan buah yang tinggi.Nilai kekerasan ini salah satu faktor yang dapat menunjukkan tingkat kesegaran buah.

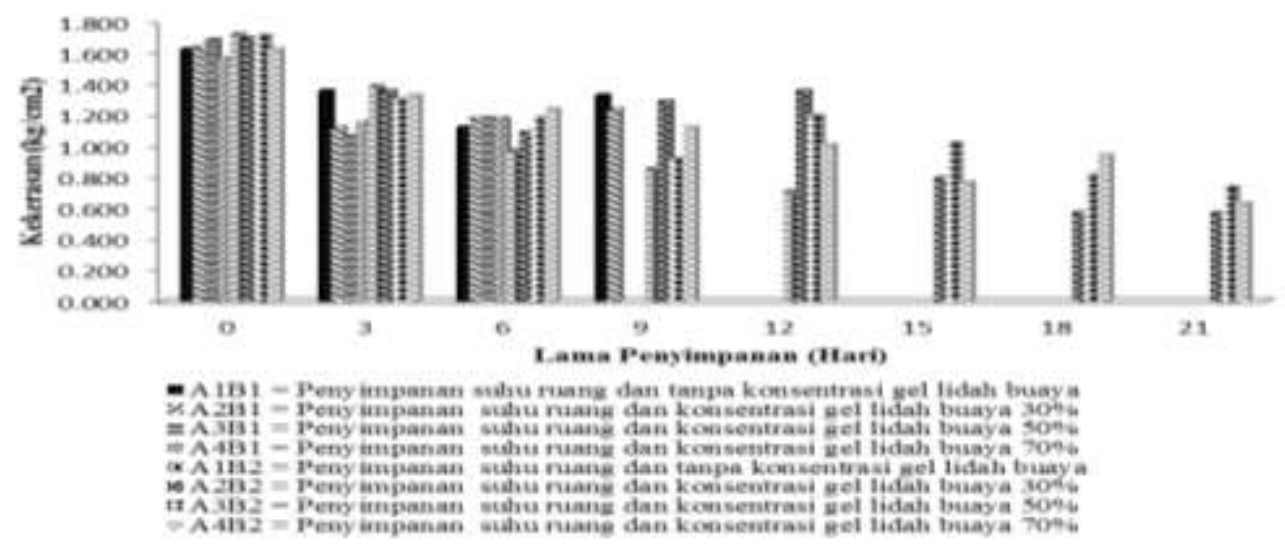

Gambar 2.Tingkat kekerasan tomat pada berbagai perlakuan konsentrasi gel lidah buaya dan suhu penyimpanan.

Gambar 2 menunjukkan bahwa nilai persentase kekerasan rata-rata tomat pada penyimpanan suhu ruang dengan konsentrasi gel lidah buaya bertahan hingga hari ke 9, pada penyimpanan suhu rendah $10^{\circ} \mathrm{C}$ dengan konsentrasi gel lidah buaya bertahan hingga hari ke 21 . Sedangkan perlakuan terbaik terdapat pada konsentrasi A1B2 berkisar $1,72 \mathrm{~kg} / \mathrm{cm}^{2}$. Suhu dingin sangat mempengaruhi perubahan nilai kekerasan buah.Semakin rendah suhu penyimpanan semakin lambat penurunan nilai kekerasan buah.Salah satu bentuk penilaian bahwa suatu produk pertanian masih layak simpan untuk dikonsumsi adalah ketika tekstur buah masih cukup keras.Pada penyimpanan dengan suhu ruang, buah cepat menjadi lunak. Penurunan tingkat kekerasan ini terjadi akibat proses pematangan sehingga komposisi dinding sel berubah menyebabkan menurunnya tekanan turgor sel dan kekerasan buah menurun. Perubahan kekerasan ini dapat dijadikan indikator tingkat kematangan buah.

\section{Vitamin C}

Kandungan vitamin $\mathrm{C}$ pada buah tomat selama penyimpanan dengan berbagai perakuan konsentrasi berkisar antara $0,70 \mathrm{mg} / 50 \mathrm{gr}-5,46 \mathrm{mg} / 50 \mathrm{gr}$. Grafik persentase vitamin $\mathrm{C}$ dapat dilihat pada Gambar 3.

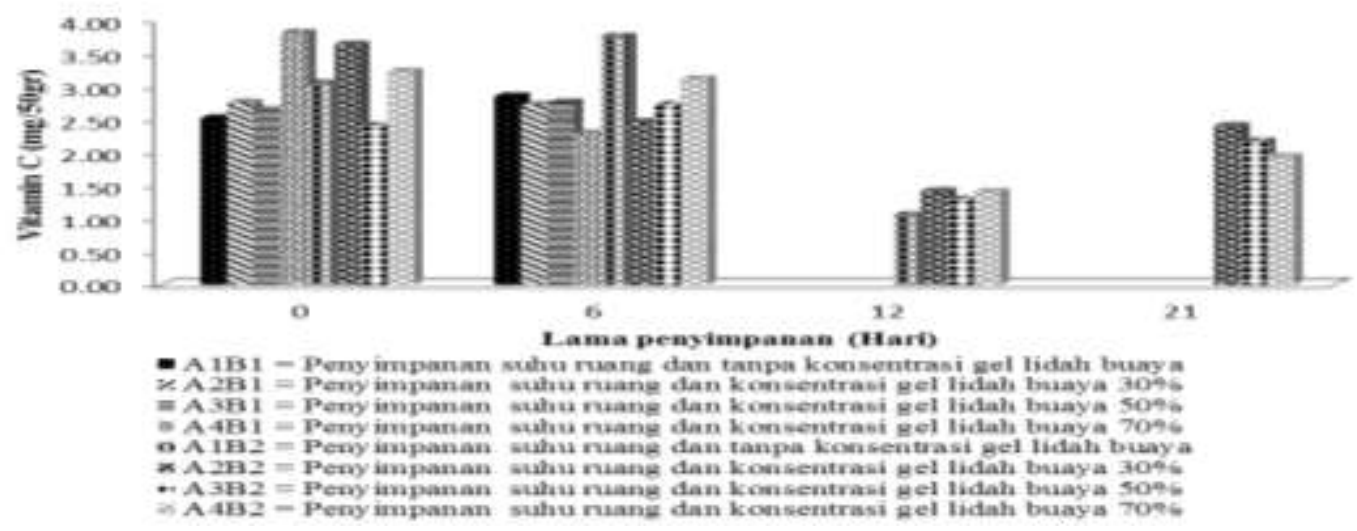

Gambar 3.Vitamin $\mathrm{C}$ tomat pada berbagai perlakuan konsentrasi gel lidah buaya dan suhu penyimpanan. 
Pada Gambar 3 diatas menunjukkan bahwa nilai persentase vitamin $\mathrm{C}$ rata-rata tomat pada penyimpanan suhu ruang dengan konsentrasi gel lidah buaya bertahan hingga hari ke 9 , pada penyimpanan suhu rendah $10^{\circ} \mathrm{C}$ dengan konsentrasi gel lidah buaya bertahan hingga hari ke 21. Sedangkan perlakuan terbaik terdapat pada konsentrasi A4B1 berkisar 3,81 mg/50gr. Selama penyimpanan kandungan vitaminC pada buah tomat terus menurun seiring dengan lamanya penyimpanan. Penyimpanan pada suhu $10^{\circ} \mathrm{C}$ buah tomat lebih lama bertahan dan lebih menurun kadar vitamin $\mathrm{C}$ akibat buah yang terlalu masak selama penyimpanan. Sedangkan pada suhu ruang buah tomat tidak lama bertahan hanya bertahan hingga hari ke 6 dan pada hari ke 6 vitamin $C$ masih mengalami kesegaran sehingga kadar vitamin $C$ nya lebih tinggi pada konsentrasi A4B1. Sesusai dengan pengamatan Masfufatun dkk,(2009)vitamin C bersifat tidak stabil, mudah teroksidasi jika terkena udara (oksigen) dan proses ini dapat dipercepat oleh panas.

\section{Total Padatan Terlarut (TPT)}

Hasil penelitian ini kadar total padatan terlarut pada buah tomat selama penyimpanan berkisar antara lain 1,10\% Brix - 4,90\%Brix. Pengukurannya dilakukan dengan menggunakan refaktometer abbe. Grafik persentase total padatan terlarut dapat dilihat pada Gambar 9.

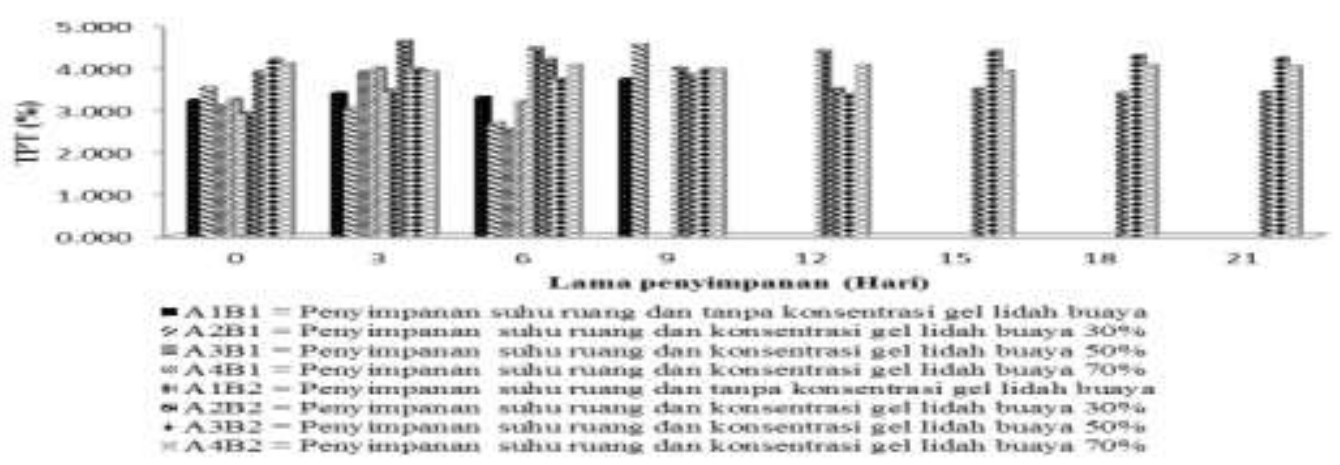

Gambar 4. Total padatan terlarut tomat pada berbagai perlakuan konsentrasi gel lidah buaya pada suhu penyimpanan.

Pada Gambar 4menunjukkan bahwa nilai persentase kekerasan rata-rata tomat pada penyimpanan suhu ruang dengan konsentrasi gel lidah buaya bertahan hingga hari ke 9, pada penyimpanan suhu rendah $10^{\circ} \mathrm{C}$ dengan konsentrasi gel lidah buaya bertahan hingga hari ke 21 . Sedangkan perlakuan terbaik terdapat pada konsentrasi A1B2 berkisar 4,47\%Brik. Menurut Novaliana (2008) kualitas buah ditentukan oleh kandungan kadar gula sebagai total padatan terlarut. Hal ini disebabkan karena buah tomat setelah pasca panen dan masa penyimpanan masih mengalami perubahan fisiologi hingga memasuki masa kelayuan, penurunan gula dan padatan terlarut lainnya.Namun demikian tidak ada perbedaan kecepatan penurunan pada perlakuan yang diberikan pada hari pengamatan.Perlakuan gel lidah buaya edible coating berfungsi menahan transpirasi sehingga menurunkan aktivitas metabolisme yang menandai perubahan kimiawi dan fisik buah.

\section{Organoleptik}

\section{Warna}

Warna meningkatkan daya tarik bahan mentah, dan sebagai petunjuk kemasan.Pada penyimpanan ke 12 konsentrasi A1B1, A2B1, A3B1 dan A4B1 sudah ditolak oleh panelis, pada penyimpanan hari ke 15 konsentrasi A2B2 sudah ditolak oleh panelis, sedangkan kesukaan warna pada suhu dingin $10^{\circ} \mathrm{C}$ A2B2, A3B2, A4B2 bertahan hingga panelis menolak yaitu pada 
penyimpanan hari ke 21. Grafik persentase penilaian panelis terhadap warna buah tomat dapat dilihat pada Gambar 5.

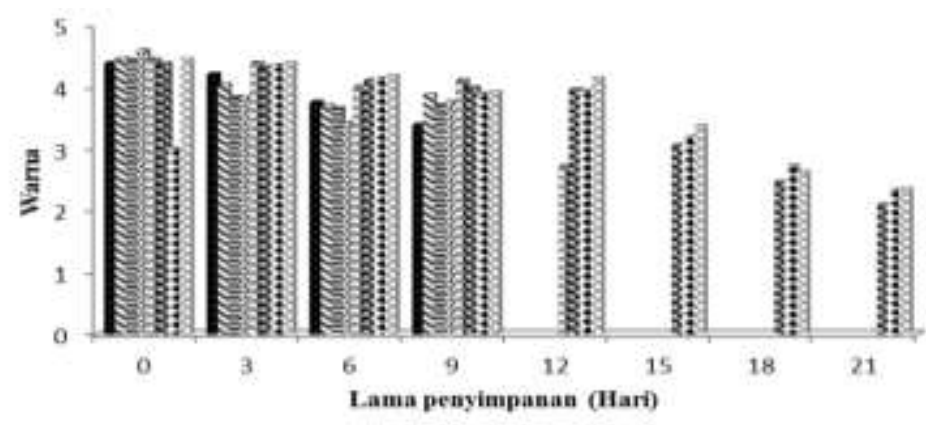

- A1B1 = Peny impanan suhu ruang dan tunpa konsentrasi gel lidah buaya 6 A $2 B 1$ = Peny impanan suhu ruang dan konsentrasi gel lidah buaya $30 \%$ $=\mathrm{A} 3 \mathrm{~B} 1=$ Peny impanan suhu ruang dan konsentrasi gel lidah buaya $50 \%$ n A 4B1 = Penyimpanan suhu ruang dan konsentrasi gel lidah boaya $70 \%$ * A $1 B 2$ = Penyimpanan suhu ruang dan tanpa konsentrasi gel lidah buaya $* A 2 B 2=$ Penyimpanan suhu ruang dan konsentrasi gel lidah buaya $30 \%$ 1* A 3 B2 - Penyimpanan suhu nuag dan konsentrasi gel lidah buaya $50 \%$ s. A 4B2 - Penyimpanan suhu ruang dan konsentrasi gel lidah beaya $70 \%$

Gambar 5. Hubungan penilaian kesukaan warna yang diberikan oleh panelis selama penyimpanan

Gambar 5 menunjukkan bahwa skor persentase kesukaan tertinggi warna tomat di hari ke 0 terdapat penyimpanan suhu ruang dan konsentrasi gel lidah buaya $70 \%$ adalah berkisar antara 4 (suka), namun seiring berjalannya waktu skor yang diberikan panelis semakin menurun. Dan untuk skor terendah selama penyimpanan pada hari ke 21 terhadap penyimpanan suhu $10^{\circ} \mathrm{C}$ dan konsentrasi gel lidah buaya $30 \%$ yaitu 2 (suka). Dari hasil uji organoleptik penilaian responden pada tingkat kesukaan terhadap warna buah tomat selama penyimpanan menunjukkan nilai yang berbeda-beda untuk tiap konsenstrasi.Selama masa penyimpanan buah tomat terus mengalami perubahan warna seiring dengan lama penyimpanan, buah tomat mengalami pematangan sempurna (kelewat masak) sehingga tomat tersebut mengalami pembusukan yaitu kulit buah tomat telah adanya bercak-bercak putih dan hitam.

\section{Aroma}

Pada penyimpana ke 12 konsentrasi A1B1, A2B1, A3B1 dan A4B1 sudah ditolak oleh panelis, pada penyimpanan hari ke 15 konsentrasi $A 2 B 2$ sudah ditolak oleh panelis, sedangkan kesukaan aroma pada suhu dingin $10^{\circ} \mathrm{C}$ A2B2, A3B2, A4B2 bertahan hingga panelis menolak yaitu pada penyimpanan hari ke 21 .

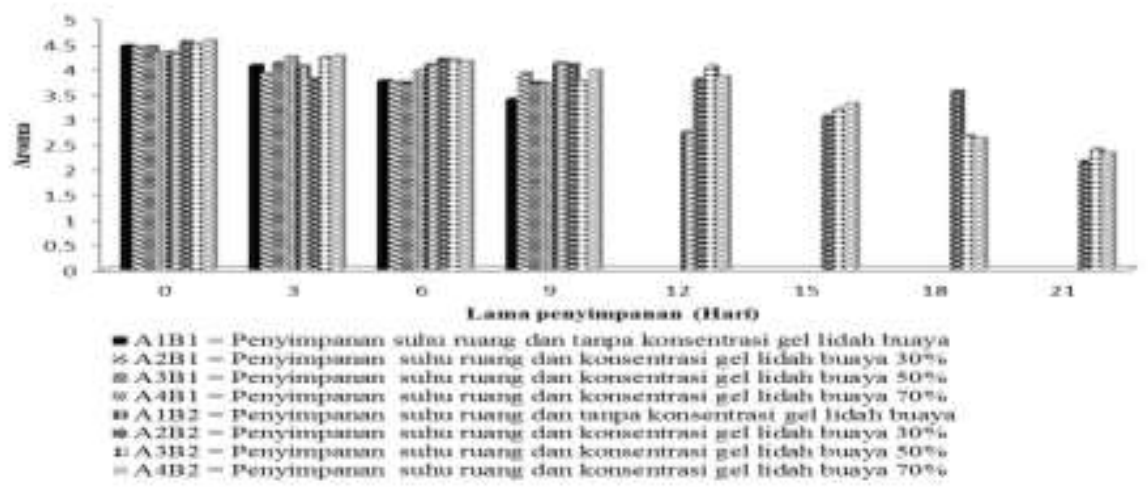

Perubahan Mutu Tomat (Lycopersicon esculentum Mill.) Dengan Variasi Konsentrasi Gel Lidah Buaya (Aloe vera L.) dan Suhu Penyimpanan.(Rina Marwina, Raida Agustina, Bambang Sukarno Putra) 
Gambar 6. Hubungan penilaian kesukaan aroma yang diberikan oleh panelis selama penyimpanan

Gambar 6 menunjukkan bahwa persentase tertinggi kesukaan terhadap aroma tomat di hari ke 0 terdapat pada penyimpanan suhu ruang dan konsentrasi lidah buaya $30 \%$ adalah berkisar antara 4 (suka), namun seiring berjalannya waktu skor yang diberikan panelis semakin menurun. Pada hari ke 21 untuk skor terendah selama terdapat pada penyimpanan suhu $10^{\circ} \mathrm{C}$ dan konsentrasi lidah buaya 30\% sebesar 2 (suka). Bau dan rasa membedakan bahan makanan yang satu dari yang lain sifat itu sukar dinilai dengan alat-alat, dan kebanyakan masih dinilai dengan cara-cara subjektif seperti panel perasa Pantastico (1986) sedangkan menurut Soekarto (1995), aroma suatu produk dalam banyak hal menentukan enak atau tidaknya suatu produk, bahkan aroma atau bau-bauan lebih komplek dari pada ras. Dan kepekaan indera pembauan biasanya lebih tinggi dari indera pencicipan, bahkan industri pangan menganggap bauk, karena dapat dengan cepat memberikan hasil penilaian suatu produk disukai atau tidak.

\section{Tekstur}

Pada penyimpana ke 12 konsentrasi A1B1, A2B1, A3B1 dan A4B1 sudah ditolak oleh panelis, pada penyimpanan hari ke 15 konsentrasi A2B2 sudah ditolak oleh panelis, sedangkan kesukaan tekstur pada suhu dingin $10^{\circ} \mathrm{C}$ A2B2, A3B2, A4B2 bertahan hingga panelis menolak yaitu pada penyimpanan hari ke 21 . Grafik persentase penilaian panelis terhadap tekstur buah tomat biji dapat dilihat pada Gambar 7.

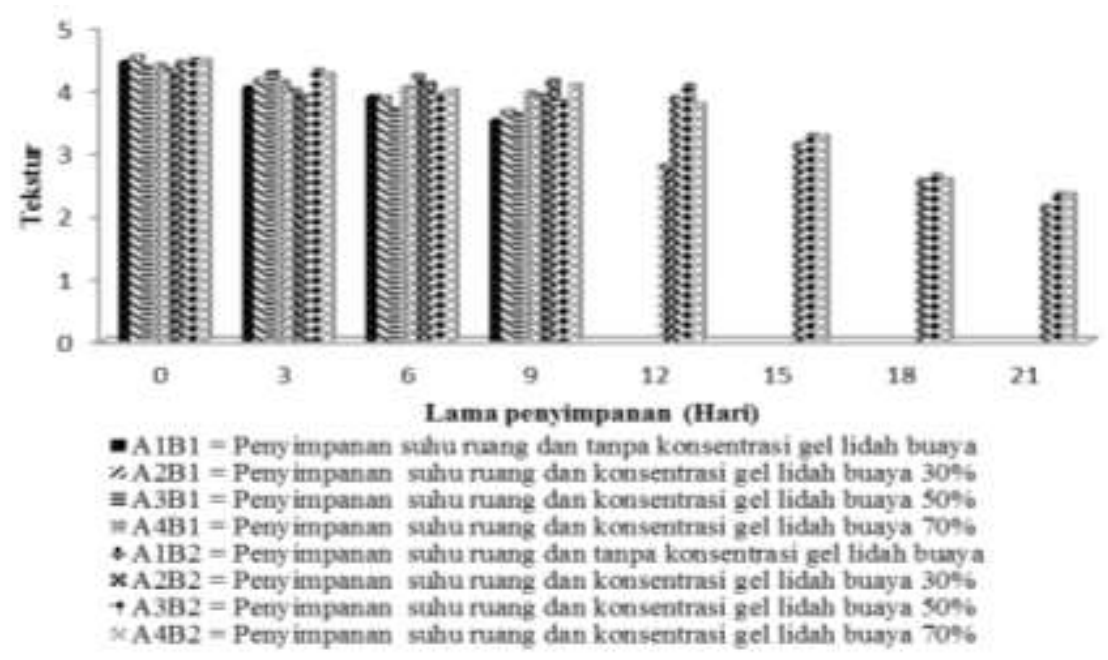

Gambar 7. Hubungan Penilaian Kesukaan Tekstur yang Diberikan oleh Panelis Selama Penyimpanan

Hasil uji organoleptik dari tingkat kesukaan panelis terhadap tekstur buah tomat pada perlakuan variasi konsentrasi gel lidah buaya dan suhu penyimpanan akan menurun seiring dengan lamanya penyimpanan. Pada hari ke 0 untuk skor tertinggi selama penyimpanan yaitu buah tomat dengan konsentrasi A2B1 sebesar 4 (suka). Dan untuk skor terendah selama penyimpanan yaitu pada buah tomat dengan konsentrasi A2B2 yaitu 2 (tidak suka). Pengujian organoleptik tekstur pada buah tomat adalah satu cara yang dapat menunjukkan tingkat kesegaran terhadap buah tersebut. Secara umum tingkat kesukaan panelis terhadap tekstur buah tomat yang disimpan pada suhu ruang cenderung lebih cepat busuk dibandingkan dengan buah jambu biji yang disimpan pada suhu dingin. Hal ini disebabkan dikarenakan buah yang disimpan pada suhu ruang cepat layu dan kelihatan tidak segar. 


\section{KESIMPULAN DAN SARAN}

Hasil penelitian didapatkan perlakuan terbaik pada tomat dengan perlakuan konsentrasi gel lidah buaya $30 \%$ pada penyimpanan suhu rendah $10^{\circ} \mathrm{C}$ masih diterima konsumen hingga hari ke 21. Penyimpanan perlakuan terbaik pada hari ke-12 untuk analisis susut bobot terdapat pada perlakuan konsentrasi gel lidah buaya $30 \%$ yang disimpan pada suhu $10^{\circ} \mathrm{C}$ dengan nilai $15,52 \%$, untuk analisis presentase kekerasan perlakuan terbaik terdapat pada konsentrasi $30 \%$ pada suhu rendah $10^{\circ} \mathrm{Cnilai}$ yaitu $1.357 \mathrm{~kg} / \mathrm{cm}^{2}$, dan analisis vitamin $\mathrm{C}$ perlakuan terbaik terdapat pada konsentrasi $30 \%$ pada suhu rendah $10^{\circ} \mathrm{Cnilai} 1,42 \mathrm{mg} / 50 \mathrm{gr}$, sedangkan TPT perlakuan terbaik terdapat pada suhu rendah $10^{\circ} \mathrm{Cdengan}$ perlakuan tanpa konsetrasi gel lidah buaya nilai presentase yaitu 4,40 \% Brix. Lama penyimpanan susut bobot, kekerasan, uji vitamin $\mathrm{C}$, total padatan terlarut, dan organoleptik (warna, aroma, tekstur) tomat yang dilapisi dengan konsentrasi perlakuan gel lidah buaya yang disimpan pada suhu ruang bertahan hingga hari ke 9 , sedangkan pada penyimpanan suhu rendah $10^{\circ} \mathrm{C}$ bertahan hingga hari ke 21 . Perlu dilakukan penelitian lanjutan pada penyimpanan buah tomat dengan berbagai perlakuan konsentrasi gel lidah buaya dengan suhu yang lebih bervariasi.

\section{DAFTAR PUSTAKA}

Apriyantono, A. 1989.Petunjuk laboratoriu manalisis pangan. Departemen Pendidikan dan Kebudayaan Direktorat Jendral Pendidikan Tinggi Pusat Antar Universitas Pangan dan Gizi, Institut Pertanian Bogor, Bogor.

http://www.academia.edu/3526062/Apriyantono_A_Fardiaz_D_Puspitasari_NL_Yasni_ S_Budijanto_S._1989._Petunjuk_Laboratorium_Analisis_Pangan._Departemen_Pendid ikan_dan_Kebudayaan._Pusat_Antar_ [3 Januari 2015].

Gardjito, M dan Wardana. 2003. Hortikultural Teknik Analisis Pasca Panen. Transmedia, Jakarta.

Hartono.1993. PelaksanaanBimbingandanKonseling di Institut Bogor. UniversitasPadjajaran, Bandung.

Masfufatun, Widaningsih, Nurkumala, T. Rahayuningsih. 2009, Pengaruhsuhudanwaktupenyimpananterhadap vitamin C dalamjambubiji (PsidiumGuajava).JurnalFakultas Teknik Universitas Wijaya Kusuma Surabaya.Vol. 11, No. 2.

Novaliana, N. 2008. Pengaruh pelapisan dan suhu simpan terhadap kualitas dan daya simpan buah nenas(ananascomous L Merr). Skripsi. Departemen Agronomi dan Holtikultura, Institut Pertanian Bogor, Bogor.

Pantastico, E. B., A.K. Mattoo, dan C.T. Phan. 1986. RespirasidanPuncakRespirasi. Di dalamFisiologiPascaPanen. Gajah Mada University Press, Jakarta.

Soekarto.1985.

PenilaianOrganoleptikUntukIndustriPangandanHasilPertanian.BharataKaryaAksara, Jakarta.

Sudarmadji, S.B., Haryono, Suhardi. 1997. Proseduranalisauntukbahanmakanandanpertanian, Penerbit Liberty, Yogyakarta. 
Valverde, J. M., Valero D., Domingo M., Fabian G., Salvador C., Maria Serrano. 2006. Novel edible coating based on aloe vera gel to maintain table grape quality and safety. Journal of Agricultural and Food Chemistry, 53:7807-7813. 